\title{
AN EVALUATION OF STAYSAFE.PH EXPOSURE NOTIFICATION SYSTEM DURING ITS BETA TESTING
}

\author{
Paula Joy L. Dela Cruz \\ Graduate Student, \\ La Consolacion University, Malolos City, Bulacan Philippines
}

\begin{abstract}
A number of group of software company develops an application system in helping the campaign to combat covid-19 virus. In this, the software quality standard is essentially to be applied to ensure the quality of software as well as to meet of its objectives. The Exposure Notification System is one of the application system developed in worldwide in response to the COVID19 crisis. In Philippines, the said application system was named into Staysafe.ph and was released on May 2020 as its beta version. Using the ISO 25010 quality model, the Staysafe.ph was evaluated and interpreted with the result of "Satisfactory". However, the improvement for application system was recommended to maximize its quality before it will officially release. The specified functions and features of Staysafe.ph will help provides solution to the challenges brought by covid-19 pandemic. Therefore the implementation of it is also recommended if it is officially released.
\end{abstract}

Keywords - Exposure Notification, Data Privacy, Software Quality, ISO 25010 Model.

\section{INTRODUCTION}

Nowadays, Covid-19 virus is the most common topic worldwide. Multiple numbers of deaths recorded every day is very alarming. Therefore, several software developers develop systems and applications to help stop the spread of virus. On April 2020, Google and Apple announced their partnership in able to develop a mobile application to help government and public health officials to help combat the virus. The joint forced effort of these two companies lead by the development of covid-19 contact tracing mobile application and later on it was called as Exposure Notification System. It is applicable for ios and android phone platforms. In Philippines, the beta version of application system released on May 2020, in compliance to their announcement to participate and help the challenge face by the worldwide during the pandemic.

In this, the researcher developed a research to determine and measures the software quality of Staysafe.ph Exposure Notification System using ISO 25010 and based on diverse users. Additionally, examine how Exposure
Notification System helps provide solution in terms of: reduction on the spread of covid-19 virus; responsive notification for Public Health Officials; accurate Contact Tracing; and application of Social Distancing System. The research conducted during the beta version of Staysafe.ph Exposure Notification System.

\section{LITERATURE REVIEW}

This section presents the review of relevant literatures in exposure notification, data privacy, software quality assurance, and software quality model in able to better understand the research domain.

\section{A. Exposure Notification}

On May 20, 2020, the Google Company released their first Exposure Notification API for android devices in line of their announcement to help combat the covid 19 viruses. Many different names was developed in this mobile application, it is based on the country[15]. In Philippines, the exposure notification was named as Staysafe.ph.

Staysafe.ph is one of the mobile applications released by Google Company with the partnership of Apple Company as help for the challenges faced by the worldwide [4]. It is also called as "bayanihan" platform helps notify users if they are near to persons suspected with covid 19. The mobile application also helps to the user to report their health condition to the public health official, trace users that has closed contact in covid 19 as well as helps apply social distancing system. It is community driven healthcare and Bluetooth-based contact tracing platform helps government to provide solution in problem brings by pandemic cause of covid 19 .

\section{B. Data privacy}

The information privacy or data privacy is a part of data security deals with the right handling of data. It is necessary that the data collected from the users is remain private and used for intended purpose only. There are certain laws in every country handle regarding the data privacy of persons as well as punishment which will tend to the persons who proven disobey in this law. In Philippines, the Data Privacy Act of 2012 is an act covered by the law that protects the individual 


\section{International Journal of Engineering Applied Sciences and Technology, 2021 \\ Vol. 5, Issue 11, ISSN No. 2455-2143, Pages 35-41 \\ Published Online March 2021 in IJEAST (http://www.ijeast.com)}

personal information. The vital role of information and communications technology also recognizes by the country to secure the personal information in information and communications systems in the government remains private and protected.

\section{Software Quality Assurance}

Software quality assurance as a systematic pattern and planned set of necessary actions to develop a software product conforms to the specified managerial and functional technical requirements. The time schedule and budgetary cost of the development process must also be met. It has also evaluation activities to ensure the products are accordance to its specification [7].

\section{Software Quality}

Software quality is the degree that system components meet the requirements and customer needs or expectations. The developed system must also conformance to its required specification and should error free. This software quality can be achieved through application of software quality assurance activities from early phases of its development until it is fully developed and implemented. These activities serve as filter from defects and help improve the software to assure the levels of confidence while running the system.

\section{E. ISO 25010 Quality Model}

ISO 25010 is the extension and improvement of ISO/IEC 9126 and one of the standards introduced by the international organization standardization as software quality measurement and it consists two dimensions the Quality-in-use and the Product Quality [7]. The Quality-in-use defines as "the degree to which a product used by specific users meets their needs to achieve specific goals" with five quality characteristics such as effectiveness, efficiency, satisfaction, freedom from risk, and context coverage.

Effectiveness refers to accuracy and completeness of the software to achieve specified goals required by the user.

Efficiency refers to achieve users' goals accurate and complete using software in a short period of time.

Satisfaction refers to the satisfactions of the user achieving specified goals using software. It consists of four subcharacteristics namely usefulness, trust, pleasure, and comfort.

Freedom from Risk refers to not causing any harm from economic, health, environment and so forth. The economic risk mitigation, health and safety risk mitigation, and environmental risk mitigation are the sub-characteristics of freedom from risk.
Context Coverage refers to acquire effectiveness and efficiency of the system, and having freedom from risk and satisfies the user, as well as covering its two subcharacteristics the context completeness and flexibility.

In Product Quality consists of eight quality characteristics namely functionality, efficiency, compatibility, usability, reliability, security, maintainability, and portability [8].

Functional Suitability is the degree which a system's functions meet the specifications and user's requirements. It consists of three sub-characteristics such as functional completeness, functional correctness, and functional appropriateness.

Performance efficiency is the degree of performance of the system under specific of time. It consists of three subcharacteristics such as time behavior, resource utilization, and capacity.

Compatibility is the degree to which a system can perform and exchange data from other hardware and software platform. It consists of two sub-characteristics such as coexistence and interoperability.

Usability refers to which a system achieve the user's goals with effectiveness, efficiency and satisfaction. It consists of six sub-characteristics such as appropriateness recognizability, learnability, operability, user error protection, user interface aesthetics, and accessibility.

Reliability refers to which a system performs specified functions under specified conditions in a given period of time. It consists of four sub-characteristics such as maturity, availability, fault tolerance, and recoverability.

Security is the degree to which a system secures information to unauthorized user and keeps the level of data access. It consists of four sub-characteristics such as confidentiality, integrity, non-repudiation, accountability, and authenticity.

Maintainability is the degree to which a system able to modify for its improvement and adapt changes required by environment and business. It consists of five subcharacteristics such as modularity, reusability, analyzability, modifiability, and testability.

Portability is the degree to which a system can transfer and function from one software, hardware, and environment to another. It consists of three sub-characteristics such as adaptability, installability, and replaceability. 


\section{International Journal of Engineering Applied Sciences and Technology, 2021 \\ Vol. 5, Issue 11, ISSN No. 2455-2143, Pages 35-41 \\ Published Online March 2021 in IJEAST (http://www.ijeast.com)}

\section{METHODOLOGY}

The ISO 25010 Quality Model was used as guide for the methodology of this study. The literature study took place to acquire of its quality characteristics and sub-characteristics. Both characteristics of ISO 25010 Quality Model namely Quality-in-use and Product Quality were used to test and measure the mobile application. In Quality-in-use the characteristics of Effectiveness, Efficiency, and Satisfaction were only used. In Product Quality, all characteristics except maintainability were used such as Functional Suitability, Performance Efficiency, Compatibility, Usability, Reliability, Security, and Portability. The evaluation questionnaire will disseminate to 100 respondents from Philippines (Expert and diverse users) and conduct online through Google form. The Likert Scale used as alternative answer of the respondents as measuring scale in the mobile application.

The researcher used the weighted mean formula to determine the descriptive equivalent of each dimensions and the results of the evaluation were interpreted using the indicators below:

$\begin{array}{ccc}\text { Scale } & \text { Ranges } & \text { Verbal Interpretation } \\ 5 & 4.50-5.00 & \text { Excellent } \\ 4 & 3.50-4.49 & \text { Very Satisfactory } \\ 3 & 2.50-3.49 & \text { Satisfactory } \\ 2 & 1.50-2.49 & \text { Good } \\ 1 & 1.00-1.49 & \text { Poor }\end{array}$

The observations also conducted to directly observe and test the StaySafe.ph mobile application.

\section{RESUlT AND DisCUSSION}

A total of 100 respondents were answered the distributed online questionnaires. The respondents were firstly used the mobile applications before answered the given questionnaire. The Table I shows the percentage of the characteristics of the respondents based on their, address, gender, and age.

As shown in Table I, $67 \%$ of the respondents are from National Capital Region, 32\% from Central Luzon, and 1\% from CALABARZON. In Gender, $59 \%$ is Male, $40 \%$ is Female, and $1 \%$ is preferred not to say. In Age, $22 \%$ under of 13 to 18 years old, $26 \%$ under of 19 to 24 years old, and $64 \%$ under of 25 to 64 years old.

Table I. Respondent Characteristics

\begin{tabular}{cl}
\hline \hline Respondent Characteristics & Percentage \\
\hline National Capital Region & $67 \%$ \\
\hline \hline
\end{tabular}

\begin{tabular}{lll}
\hline Location & Central Luzon & $32 \%$ \\
& CALABARZON & $1 \%$ \\
Gender & Male & $59 \%$ \\
& Female & $40 \%$ \\
& Prefer Not To Say & $1 \%$ \\
Age & 13 to 18 & $22 \%$ \\
& 19 to 24 & $26 \%$ \\
\hline \hline
\end{tabular}

Based on the distributed online evaluation questionnaires the following tables show the results. The Table II to Table VIII results is characteristics and subcharacteristics of ISO 25010 under of Product Quality.

Table II showed the results of overall weighted mean value in Functionality which is rated 3.16, and interpreted as Satisfactory.

Table II. Evaluation by the Respondents of the Functionality of Staysafe.Ph Exposure Notification

\begin{tabular}{lll}
\hline \hline Functionality. & $\begin{array}{l}\text { Mean } \\
\text { Rating }\end{array}$ & $\begin{array}{l}\text { Verbal } \\
\text { Interpretation }\end{array}$ \\
\hline $\begin{array}{l}\text { Functional Completeness. The } \\
\text { mobile application covers all the } \\
\text { specified tasks and user objectives. }\end{array}$ & & Satisfactory \\
$\begin{array}{l}\text { Functional Correctness. The mobile } \\
\text { application provides the correct with }\end{array}$ & & Satisfactory \\
the needed degree of precision. & & \\
$\begin{array}{l}\text { Functional Appropriateness. The } \\
\text { mobile application facilitates the }\end{array}$ & 3.28 & Satisfactory \\
$\begin{array}{l}\text { accomplishment of specified tasks } \\
\text { and objectives. }\end{array}$ & & \\
Average Weighted Mean & $\mathbf{3 . 1 6}$ & Satisfactory \\
\hline \hline
\end{tabular}

Table III showed the results of overall weighted mean value in Efficiency which is rated 3.18, and interpreted as Satisfactory.

Table III. Evaluation by the Respondents of the Efficiency of Staysafe.Ph Exposure Notification

\begin{tabular}{|c|c|c|}
\hline Efficiency & $\begin{array}{c}\text { Mean } \\
\text { Rating }\end{array}$ & $\begin{array}{c}\text { Verbal } \\
\text { Interpretation }\end{array}$ \\
\hline $\begin{array}{l}\text { Time Behavior. The mobile } \\
\text { application's response and processing } \\
\text { times and throughput rates when } \\
\text { performing its functions, and meet } \\
\text { requirements. }\end{array}$ & 3.01 & Satisfactory \\
\hline $\begin{array}{l}\text { Resource Utilization. The mobile } \\
\text { application connects to the resources to } \\
\text { access information needed and meets } \\
\text { requirements. }\end{array}$ & 3.41 & Satisfactory \\
\hline
\end{tabular}




\begin{tabular}{|c|c|c|}
\hline $\begin{array}{l}\text { Capacity. The mobile application } \\
\text { remains working and meets } \\
\text { requirements even with a large number } \\
\text { of users access at the same time. }\end{array}$ & 3.11 & Satisfactory \\
\hline Average Weighted Mean & 3.18 & Satisfactory \\
\hline
\end{tabular}

Table IV showed the results of overall weighted mean value in Compatibility which is rated 3.85, and interpreted as Very Satisfactory.

Table IV. Evaluation by the Respondents of the Compatibility of Staysafe.Ph Exposure Notification

\begin{tabular}{|c|c|c|}
\hline Compatibility & $\begin{array}{l}\text { Mean } \\
\text { Rating }\end{array}$ & $\begin{array}{c}\text { Verbal } \\
\text { Interpretation }\end{array}$ \\
\hline $\begin{array}{l}\text { Co-existence. The mobile } \\
\text { application can perform its required } \\
\text { functions efficiently while sharing a } \\
\text { common environment and resources } \\
\text { with other products, without } \\
\text { detrimental impact on any other } \\
\text { product. }\end{array}$ & 3.95 & Very Satisfactory \\
\hline $\begin{array}{l}\text { Interoperability. The mobile } \\
\text { application can exchange information } \\
\text { and use the information that has been } \\
\text { exchanged. }\end{array}$ & 3.74 & Very Satisfactory \\
\hline Average Weighted Mean & 3.85 & Very Satisfactory \\
\hline
\end{tabular}

Table $\mathrm{V}$ showed the results of overall weighted mean value in Usability which is rated 3.40 , and interpreted as Satisfactory.

TABLE V. EVALUATION BY THE RESPONDENTS OF THE USABILITY OF STAYSAFE.PVH EXPOSURE NOTIFICATION

\begin{tabular}{|c|c|c|}
\hline Usability & $\begin{array}{l}\text { Mean } \\
\text { Rating }\end{array}$ & $\begin{array}{c}\text { Verbal } \\
\text { Interpretation }\end{array}$ \\
\hline $\begin{array}{l}\text { Appropriateness Recognizability. } \\
\text { The mobile application allows users } \\
\text { to recognize if it is appropriate for } \\
\text { their needs. }\end{array}$ & 3.47 & Satisfactory \\
\hline $\begin{array}{l}\text { Learnability. The mobile } \\
\text { application can be used by specified } \\
\text { users to achieve specified goals of } \\
\text { learning to use the application with } \\
\text { effectiveness, efficiency, freedom } \\
\text { from risk, and satisfaction in a } \\
\text { specified context of use. }\end{array}$ & 3.47 & Satisfactory \\
\hline $\begin{array}{l}\text { Operability. The mobile application } \\
\text { has attributes that make it easy to } \\
\text { operate and control. }\end{array}$ & 3.48 & Satisfactory \\
\hline $\begin{array}{l}\text { User Error Protection. The mobile } \\
\text { application protects users against } \\
\text { making errors. }\end{array}$ & 3.16 & Satisfactory \\
\hline $\begin{array}{l}\text { User Interaction Aesthetics. The } \\
\text { mobile application's user interface } \\
\text { enables pleasing and satisfying } \\
\text { interaction for the user. }\end{array}$ & 3.42 & Satisfactory \\
\hline $\begin{array}{l}\text { Accessibility. The mobile } \\
\text { application can be used by people } \\
\text { with the widest range of }\end{array}$ & 3.42 & Satisfactory \\
\hline
\end{tabular}

characteristics and capabilities to achieve a specified goal in a specified context of use.
Average Weighted Mean
3.40
Satisfactory

Table VI showed the results of overall weighted mean value in Reliability which is rated 3.24, and interpreted as Satisfactory.

Table VI. Evaluation by the Respondents of the Reliability of Staysafe.Ph Exposure Notification

\begin{tabular}{ccc}
\hline Reliability. & $\begin{array}{c}\text { Mean } \\
\text { Rating }\end{array}$ & $\begin{array}{c}\text { Verbal } \\
\text { Interpretation }\end{array}$ \\
\hline $\begin{array}{c}\text { Maturity. The mobile application } \\
\text { meets the needs for reliability under } \\
\text { normal operation }\end{array}$ & 3.31 & Satisfactory \\
$\begin{array}{c}\text { Availability. The mobile application } \\
\text { is operational and accessible when } \\
\text { required for use. }\end{array}$ & 3.29 & Satisfactory \\
$\begin{array}{c}\text { Fault Tolerance. The mobile } \\
\text { application operates as intended } \\
\text { despite the presence of hardware or } \\
\text { software faults. }\end{array}$ & 3.13 & Satisfactory \\
$\begin{array}{c}\text { Recoverability. The mobile } \\
\text { application can recove } \\
\text { and re-establish the desired state. }\end{array}$ & 3.22 & Satisfactory \\
& & \\
Average Weighted Mean & $\mathbf{3 . 2 4}$ & Satisfactory \\
\hline \hline
\end{tabular}

Table VII showed the results of overall weighted mean value in Security which is rated 4.03, and interpreted as Very Satisfactory.

Table VII. Evaluation by the Respondents of the Security of Staysafe.Ph Exposure Notification

Table VIII showed the results of overall weighted mean value in Portability which is rated 4.01, and interpreted as Very Satisfactory.

Table VIII. Evaluation by the Respondents of the Portability of Staysafe.Ph Exposure Notification

\begin{tabular}{lcc}
\hline \hline \multicolumn{1}{c}{ Portability } & $\begin{array}{c}\text { Mean } \\
\text { Rating }\end{array}$ & $\begin{array}{c}\text { Verbal } \\
\text { Interpretation }\end{array}$ \\
\hline $\begin{array}{l}\text { Installability. The application can } \\
\text { install different platform such as } \\
\text { smartphone and computer. }\end{array}$ & 3.99 & Very Satisfactory \\
\hline \hline
\end{tabular}

\begin{tabular}{|c|c|c|}
\hline Security & $\begin{array}{l}\text { Mean } \\
\text { Rating }\end{array}$ & $\begin{array}{c}\text { Verbal } \\
\text { Interpretation }\end{array}$ \\
\hline $\begin{array}{l}\text { Confidentiality. The mobile } \\
\text { application ensures that data are } \\
\text { accessible only to those authorized to } \\
\text { have access. }\end{array}$ & 4.15 & Very Satisfactory \\
\hline $\begin{array}{l}\text { Integrity. The mobile application } \\
\text { prevents unauthorized access or } \\
\text { modification of data. }\end{array}$ & 4.01 & Very Satisfactory \\
\hline $\begin{array}{l}\text { Non-repudiation. The mobile } \\
\text { application can be proven to have } \\
\text { taken place so that the events or } \\
\text { actions cannot be repudiated later. }\end{array}$ & 3.93 & Very Satisfactory \\
\hline Average Weighted Mean & 4.03 & Very Satisfactory \\
\hline
\end{tabular}




\begin{tabular}{lcc}
\hline \hline $\begin{array}{l}\text { Replaceability. The application is } \\
\text { applicable to android, ios, and } \\
\text { other operating systems. }\end{array}$ & 4.03 & Very Satisfactory \\
Average Weighted Mean & $\mathbf{4 . 0 1}$ & Very Satisfactory \\
\hline
\end{tabular}

The Table IX to Table XI results is characteristics and sub- characteristics of ISO 25010 under of Quality-in-use model.

Table IX showed the results of overall weighted mean value in Effectiveness which is rated 2.86, and interpreted as Satisfactory.

Table IX. Evaluation by the Respondents of the Effectiveness of

\begin{tabular}{|c|c|c|}
\hline \multicolumn{3}{|c|}{ Staysafe.Ph Exposure Notification } \\
\hline Effectiveness & $\begin{array}{l}\text { Mean } \\
\text { Rating }\end{array}$ & $\begin{array}{c}\text { Verbal } \\
\text { Interpretation }\end{array}$ \\
\hline $\begin{array}{l}\text { The mobile application determines if } \\
\text { there are persons exposed and } \\
\text { possible infected of covid-19 virus. } \\
\text { The mobile application notifies the } \\
\text { Public Health Officials immediately } \\
\text { once the user is possible of being } \\
\text { positive in covid } 19\end{array}$ & 2.91 & Satisfactory \\
\hline $\begin{array}{l}\text { The mobile application traces and } \\
\text { alerts the close contacts of covid } 19 \\
\text { patients. }\end{array}$ & 2.78 & Satisfactory \\
\hline $\begin{array}{l}\text { The mobile application notifies the } \\
\text { user to apply social distancing } \\
\text { system. }\end{array}$ & 2.9 & Satisfactory \\
\hline Average Weighted Mean & 2.86 & Satisfactory \\
\hline
\end{tabular}

Table X showed the results of overall weighted mean value in Efficiency which is rated 2.94, and interpreted as Satisfactory.

Table X. Evaluation by the Respondents of the Efficiency of Staysafe.Ph

\begin{tabular}{lcc}
\multicolumn{1}{c}{ Exposure Notification } & \\
\hline \hline & $\begin{array}{c}\text { Mean } \\
\text { Rating }\end{array}$ & $\begin{array}{c}\text { Verbal } \\
\text { Interpretation }\end{array}$ \\
\hline $\begin{array}{l}\text { The mobile application notify the } \\
\text { user right after detecting if there's } \\
\text { possible infected of covid-19 virus } \\
\text { nearest on the location. }\end{array}$ & 2.98 & Satisfactory \\
$\begin{array}{l}\text { The mobile application sending } \\
\text { request to Public Health Officials } \\
\text { and return a response rapidly. }\end{array}$ & 2.85 & Satisfactory \\
$\begin{array}{l}\text { The mobile application detects the } \\
\text { close contacts of covid 19 patients } \\
\text { in a short period of time. }\end{array}$ & 2.96 & Satisfactory \\
$\begin{array}{l}\text { The mobile application applies } \\
\text { social distancing } \quad \text { system } \\
\text { immediately after detecting } \\
\text { persons around the location, and } \\
\text { implementing social distancing to } \\
\text { the user. }\end{array}$ & & \\
Average Weighted Mean & $\mathbf{2 . 9 4}$ & Satisfactory \\
\hline \hline
\end{tabular}

Table XI showed the results of overall weighted mean value in Efficiency which is rated 3.27, and interpreted as Satisfactory.

Table XI. Evaluation by the Respondents of the Satisfaction of Staysafe.Ph Exposure Notification

\begin{tabular}{|c|c|c|}
\hline Satisfaction & $\begin{array}{l}\text { Mean } \\
\text { Rating }\end{array}$ & $\begin{array}{c}\text { Verbal } \\
\text { Interpretation }\end{array}$ \\
\hline $\begin{array}{l}\text { Usefulness. The mobile application } \\
\text { can reduce the spread of covid-19 } \\
\text { virus, responsive on notifying } \\
\text { Public Health Official, accurate in } \\
\text { Tracing of closed contacts, and } \\
\text { apply social distancing system. } \\
\text { Trust. The mobile application is } \\
\text { reliable in reduction on the spread } \\
\text { of covid-19 virus, responsive in } \\
\text { notification for Public Health } \\
\text { Officials, accurate in tracing closed } \\
\text { contacts, and applies social } \\
\text { distancing system. }\end{array}$ & 2.94 & Satisfactory \\
\hline $\begin{array}{l}\text { Pleasure. The important functions } \\
\text { and features of mobile application } \\
\text { give fulfillment. }\end{array}$ & 3.23 & Satisfactory \\
\hline $\begin{array}{l}\text { Comfort. The mobile application } \\
\text { helps give solution the challenges } \\
\text { bring of the pandemic. }\end{array}$ & 4.04 & Very Satisfactory \\
\hline Average Weighted Mean & 3.27 & Satisfactory \\
\hline
\end{tabular}

Table XII showed the summary of overall weighted mean value in Product Quality which is rated 3.55, and interpreted as Very Satisfactory.

Table XII. Summary of Overall Evaluation by the Respondents in

\begin{tabular}{lccc}
\multicolumn{2}{c}{ Criteria } & $\begin{array}{c}\text { Mean } \\
\text { Rating }\end{array}$ & $\begin{array}{c}\text { Verbal } \\
\text { Interpretation }\end{array}$ \\
\hline \hline Functionality & 3.16 & Satisfactory \\
Efficiency & 3.18 & Satisfactory \\
Compatibility & 3.85 & Very Satisfactory \\
Usability & 3.40 & Satisfactory \\
Reliability & Security & 3.24 & Satisfactory \\
& Portability & 4.03 & Very Satisfactory \\
& 4.01 & Very Satisfactory \\
\multicolumn{2}{c}{ Average Weighted Mean } & $\mathbf{3 . 5 5}$ & Very Satisfactory \\
& & \\
\hline \hline
\end{tabular}

Table XIII showed the summary of overall weighted mean value in Quality in Use which is rated 3.02, and interpreted as Satisfactory.

Table XIII. Summary of Overall Evaluation by the Respondents in Quality-in-Use Model of ISO 25010

\begin{tabular}{lcc}
\hline \hline Criteria & $\begin{array}{c}\text { Mean } \\
\text { Rating }\end{array}$ & $\begin{array}{c}\text { Verbal } \\
\text { Interpretation }\end{array}$ \\
\hline Effectiveness & 2.86 & Satisfactory \\
Efficiency & 2.94 & Satisfactory
\end{tabular}




\begin{tabular}{ccc} 
Satisfaction & 3.27 & Satisfactory \\
Average Weighted Mean & $\mathbf{3 . 0 2}$ & Satisfactory \\
\hline \hline
\end{tabular}

\section{CONCLUSIONS}

The functions and features of StaySafe.ph Exposure Notification System in terms of reduction on the spread of covid-19 virus, responsive notification for Public Health Officials, accurate Contact Tracing, and application of Social Distancing System will help provide solutions in the pandemic experienced by many people worldwide caused by covid-19. However, based on the results of the overall weighted mean for Product Quality "3.55" with descriptive equivalent of "Very Satisfactory", and the overall weighted mean for Quality-in-Use "3.02" with descriptive equivalent of "Satisfactory" the researcher conclude that the improvement and enhancement to the StaySafe.ph Exposure Notification System must be retained before it will be officially released, in order to meet its goals and objectives. Once it is fully developed, the testing and implementation of StaySafe.ph Exposure Notification System is recommended to help the community, leaders, health officials, front liners as well as the government to fight against covid-19.

\section{REFERENCES}

[1] Ahmed N, Michelin RA, Xue W, Ruj S, Malaney, et al. (2020). A Survey of COVID-19 Contact Tracing Apps," in IEEE Access, vol. 8. 134577-134601. doi: 10.1109/ACCESS.2020.3010226.

[2] Altmann, S., Milsom, L., Zillessen, H., Blasone, R., Gerdon, F., Bach, R., Kreuter, F., Nosenzo, D., Toussaert, S., \& Abeler, J. (2020). Acceptability of App-Based Contact Tracing for COVID-19: Cross-Country Survey Study. JMIR MHealth and UHealth, 8(8), e19857. https://doi.org/10.2196/19857

[3] Anglemyer, A., Moore, T. H. M., Parker, L., Chambers, T., Grady, A., Chiu, K., Parry, M., Wilczynska, M., Flemyng, E., \& Bero, L. (2020). Digital contact tracing technologies in epidemics: a rapid review. Cochrane Database of Systematic Reviews, 3-6. https://doi.org/10.1002/14651858.cd013699

[4] Apple. (2020). Privacy-Preserving Contact Tracing Apple and https://covid19.apple.com/contacttracing

[5] Atanacio, M., and Lacatan, L. (2019). Development and Evaluation of Rural Health Unit Record Management System with Data Analytics for Municipality of Bay, Laguna using ISO 25010. International Journal of Recent Technology and Engineering, 8(3), 3915-3919. https://doi.org/10.35940/ijrte.c5133.098319

[6] Boehm, B. E. W. A. (1978). Characteristics of software quality (TRW series of software technology) (1st ed.). American Elsevier.
[7] Haslinda et al., "Evaluation of e-Book applications using ISO 25010," 2015 International Symposium on Technology Management and Emerging Technologies (ISTMET), Langkawi, Malaysia, 2015, pp. 114-118, doi: 10.1109/ISTMET.2015.7359012.

[8] Hussain, A., \& Mkpojiogu, E. O. C. (2015). AN APPLICATION OF THE ISO/IEC 25010 STANDARD IN THE QUALITY-IN-USE ASSESSMENT OF AN ONLINE HEALTH AWARENESS SYSTEM. Jurnal Teknologi, 77(5), 9-10. https://doi.org/10.11113/jt.v77.6107

[9] Izzatillah, M. (2019). QUALITY MEASUREMENT OF TRANSPORTATION SERVICE APPLICATION GOJEK USING ISO 25010 QUALITY MODEL. Simetris: Jurnal Teknik Mesin, Elektro Dan Ilmu Komputer, 10(1), 233-242. https://doi.org/10.24176/simet.v10i1.2945

[10] Kleinman, R. A., \& Merkel, C. (2020). Digital contact tracing for COVID-19. Canadian Medical Association Journal, 192(24), E653-E656. https://doi.org/10.1503/cmaj.200922

[11]Liulliyah, L., \& Pribadi Subriadi, A. (2020). Performance Measurement of Academic Information Systems using Performance Prism and ISO/IEC 25010. The Winners, 21(2), 76-77. https://doi.org/10.21512/tw.v21i2.6505

[12] Nowostawski, M. (2020). Mobile Phone Based Contact Tracing Applications for Combating Covid-19 Pandemic. Biomedical Journal of Scientific \& Technical Research, 32(4), 25194-25197. https://doi.org/10.26717/bjstr.2020.32.005286

[13]Peters, E., \& Aggrey, G. K. (2020). An ISO 25010 Based Quality Model for ERP Systems. Advances in Science, Technology and Engineering Systems Journal, 5(2), 578583. https://doi.org/10.25046/aj050272

[14] Privacy-Preserving Contact Tracing - Apple and Google. (2020). Apple. https://covid19.apple.com/contacttracing

[15] Rahman, M. (2021, February 25). Here are the countries using Google and Apple's COVID-19 Contact Tracing API. Xda-Developers. https://www.xdadevelopers.com/google-apple-covid-19-contact-tracingexposure-notifications-api-app-list-countries/

[16] Ranisch, R., Nijsingh, N., Ballantyne, A., van Bergen, A., Buyx, A., Friedrich, O., Hendl, T., Marckmann, G., Munthe, C., \& Wild, V. (2020). Digital contact tracing and exposure notification: ethical guidance for trustworthy pandemic management. Ethics and Information Technology, 1-3. https://doi.org/10.1007/s10676-020-09566-8

[17] Sainz F., Ali I.S., and Waddy B. (2020). Apple and Google partner on COVID-19 contact tracing technology. Apple Newsroom, [Online]. Available:https://www.apple.com/sg/newsroom/2020/04/a pple-and-google-partner-on-covid-19-contact-tracingtechnology.

[18] Wattiheluw F.H., Rochimah S., Fatichah C. and K. Abidin Z. (2020). Development of a Quality Model 
Based on ISO 25010 Using Fuzzy and PSO for Ecommerce Websites, 17th International Conference on Electrical Engineering/Electronics, Computer, Telecommunications and Information Technology (ECTICON), Phuket, Thailand, 250-254. doi: 10.1109/ECTICON49241.2020.915832

[19]Zastrow, M. (2020). Coronavirus contact-tracing apps: can they slow the spread of COVID-19? Nature, 1-2. https://doi.org/10.1038/d41586-020-01514-2 